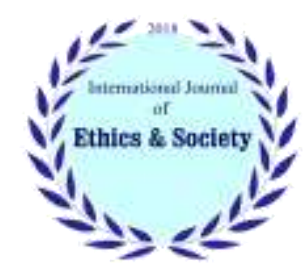

International Journal of Ethics \& Society (IJES)

Journal homepage: www.ijethics.com

Vol. 3, No. 4 (2022)

(Original article)

\title{
Variables Affecting the Creation and Development of Bank Loss Syndrome with Emphasis on Ethical Variables
}

\author{
Hamidreza Bahramí, Mansour Garkaz ${ }^{b *}$, Ali Khozain ${ }^{c}$, Alireza Maetoofi ${ }^{b}$ \\ a) Ph.D. student, Dept. of Accounting, Gorgan branch, Islamic Azad University, Gorgan, Iran \\ b) Dept. of Accounting, Gorgan Branch, Islamic Azad University, Gorgan, Iran \\ c) Dept. of Accounting, Aliabad Katoul Branch, Islamic Azad University, Aliabad Katoul, Iran
}

\begin{abstract}
Background: Awareness of prioritizing the variables affecting the threat to the security and financial health of a bank is a very important issue. Also, the appropriate and ethical use of the set priorities is a more important issue in decisions related to the merger of branches with continuous losses. The purpose of this study is to investigate the fundamental factors affecting the formation and development of loss syndrome in Bank Mellat branches with emphasis on ethical variables.

Method: The present study was qualitative and based on the data foundation approach. The statistical population included experts in the field of planning, decision-making and strategic decision-making of Bank Mellat, from which 21 people were purposefully selected as a sample. The analysis tool was interview and the data were analyzed using open, axial and selective coding.

Results: The results of open and axial coding were the estimation of 53 initial codes in the form of 11 categories out of 280 concepts which were finally positioned in the research model using selective coding.

Conclusion: In addition to conditions such as general economic conditions and inefficient management practices, inefficient decisions, lack of efficient regulatory and judicial systems, declining quality of banking services, etc., ethics can be an important factor in the occurrence of bank loss syndrome.
\end{abstract}

Keywords: Bank loss syndrome, Financial safety, Ethical factors

* Corresponding Author: Email: m.garkaz20@gmail.com

Received: 28 May 2021

Accepted: 12 Aug 2021

Copyright: (C) 2022 Garkaz M. et al. Published by Iranian Association of Ethics in Science and Technology

This article is an open access article distributed under a Creative Commons Attribution-Noncommercial 4.0

International License. (https://creativecommons.org/licenses/by-nc/4.0/ ).

Available at: www.ijethics.com 


\section{Introduction}

One of the most important sectors of any country's economy is the capital market. Economic growth can lead to the development and prosperity of the capital market. On the other hand, achieving optimal economic growth and development is impossible without efficient financial institutions and proper equipping of financial resources. In this regard, efficient financial systems can lead to better allocation of resources and ultimately increase economic growth by obtaining information about investment opportunities, consolidating and equipping savings, monitoring investments and exercising corporate governance, facilitating the exchange of goods and services, and managing risk. $(1,2)$.

The banking industry is one of the most important sectors of the country's economy, which can provide the grounds for economic growth and prosperity by properly organizing and managing its resources and expenditures (3 and 4).

Banks and financial institutions have a very important and decisive role in resource allocation, economic growth and job creation. The existence of efficient financial companies is necessary for the growth and support of economic growth for any country (5). Also, the banking industry is one of the most complex industries in the world and has a major share in the assets and wealth of countries. In the UK, $25 \%$ of GDP is generated by the financial services sector $(6,7)$.

One of the financial ills in any country is Bank Loss Syndrome. Theories of organizational syndromes in general or in particular derive from theories of organizational psychology or sociological-organizational (8). In recent years, for various reasons, bank branches have suffered continuous losses and the financial loss syndrome has emerged in them (9). Failure to correctly diagnose the type of financial disease formed and developing and metastasizing may inflict an irreparable blow on the bank and perhaps the entire banking network of the country. Hence, a new financial-ethical engineering is needed to deal with this syndrome. In addition to their core responsibilities, banks also play an important role in achieving equitable income distribu- tion, reducing poverty and class divisions, legislation, and the activities of businesses in the financial and real sectors of the economy. Influencing issues such as equitable distribution of income and reducing the level of poverty and deprivation in society, creates a special place for this system that can be defined in the context of ethical banking (10).

Ethical banking as a subset of ethics in the economy has a special place among the world's leading banks and a broad consensus has emerged on the need to develop ethical banking (11). Ethical banking is a way of showing that economic profit should not be an end in itself, but an end in which banks should pursue their mission (12). The most important ethical components in the banking industry are honesty, impartiality, trust, compliance and transparency (13).

Ethical orientations are used as a guide in decisions related to the merger or non-merger of branches and giving a deadline to this group of branches to exit the loss. In fact, the ethical approach as a new model in the banking system has a special place that the most objective presence of ethics in the banking system is the same set of rules of conduct with ethical codes.

Observing crises and problems such as non-compliance with standards and professional ethics in the field of decision-making regarding the merger of loss-making branches, makes the issue of ethics in banking decision-making important. Therefore, in the decision-making and decision-making processes for the merger of loss-making branches, the use of ethical and fair approach in order not to lose the financial rights of the manpower of the merged branches, is highly emphasized.

The recommendation is that better decisions should be made using the ethical approach to manage the variables affecting the formation and development of the loss syndrome of bank branches, which are ranked according to the network analysis method. Ethical orientations act as a guide in decisions related to the merger or non-merger of branches and granting time to these branches to eliminate losses. Therefore, in the present study, with the aim of answering the basic question: What 
are the effective variables on the creation and development of Bank 15 loss syndrome and what are the ethical factors in this regard?

\section{Material \& Methods}

The present study was qualitative and based on the data foundation approach. The statistical population included experts (managers, experts and bankers) specializing in the discussion of Bank Mellat's Balanced Scorecard (BSC) system, from which 21 people were purposefully selected as a sample. The characteristics of the sample group are presented in Table 1. The interview analysis tool was semi-structured and answered with open-ended questions. The following was done for the validity and reliability of the interviews:

1. Accurate and detailed notes of interviews

2. Using quality audio recorder for accurate recording of utterances

3. Matching the recorded files with the summarized notes and completing the details left in the note-taking

4. Using and sending an open questionnaire to those experts who, after several times and coordination, were not able to meet with them in person.

5. Resolving ambiguities by making phone calls, text messages or from cyberspace (WhatsApp and Telegram) with experts with whom it was not possible to meet in person but had answered the open questionnaire questions.

6. Reading propositions for another range of experts and open coding by them separately

7. Sharing the extracted concepts and extracting the final concepts

Finally, the data were analyzed using open, axial and selective coding methods.
Table 1: Demographic characteristics

\begin{tabular}{|ll|l|}
\hline \multirow{4}{*}{ Work experience } & 5-15ys & 7 \\
\cline { 2 - 3 } Number of articles & 16-20ys & 3 \\
\cline { 2 - 3 } & Over 21ys & 11 \\
\cline { 2 - 3 } & Less than 5 & 18 \\
\cline { 2 - 3 } Education degree & 6-10 articles & 2 \\
\cline { 2 - 3 } & More than 10 articles & 1 \\
\cline { 2 - 3 } & M.A & 7 \\
\cline { 2 - 3 } & Ph.D. student & 10 \\
\hline & Ph.D. & 6 \\
\hline
\end{tabular}

\section{Results}

\section{Open coding}

At this stage, the data obtained from the interviews were reviewed and research-related concepts were extracted. Results of qualitative data open coding 53 open codes were identified among the concepts. Axial coding

The researcher's task at this stage was to "categorize and compare" the titles extracted from the data. Axial coding leads to the creation of groups and categories. All similar codes are in their own group. In the Axial Coding section, 53 primary codes in the form of 11 categories are presented in Table 2 under the headings Categories.

\section{Selective coding}

Selective coding is the process of integrating and improving categories. At this stage of coding, a theory of the relationships between the categories in the axial coding model is written. In other words, selective coding captures the findings of previous coding steps, selects the central category, systematically relates it to other categories, proves those relationships, and the categories that need further improvement and development. It completes, therefore, the central category is a very important part of the integration and improvement of categories. Table 2 shows the categories and subcategories of the selected coding.

Table 2: Selective coding

\begin{tabular}{|c|c|c|}
\hline Type of category & \multicolumn{2}{|c|}{ Category } \\
\hline Axial category & $\begin{array}{c}\text { Imbalance and reduction of health } \\
\text { level and decrease of financial secu- } \\
\text { rity of the branch }\end{array}$ & $\begin{array}{c}\text { Asset and debt gap } \\
\text { Income-cost gap } \\
\text { Imbalance in cash flow }\end{array}$ \\
\hline
\end{tabular}




\begin{tabular}{|c|c|c|}
\hline \multirow[t]{5}{*}{ Casual conditions } & $\begin{array}{l}\text { Decreased adherence to organiza- } \\
\text { tional ethics values in the branch } \\
\text { team }\end{array}$ & $\begin{array}{c}\text { Decreased attention to organizational ethics } \\
\text { Reduce attention to work and collective effort } \\
\text { Decreased attention to eager service } \\
\text { Decreased attention to value creation and excellence } \\
\text { Reduce attention to commitment } \\
\text { Decreased attention to trust and loyalty } \\
\text { Reduce attention to the criterion of responsibility } \\
\text { Reduce attention to the ease and simplicity of processes } \\
\text { Decreased attention to the criterion of transparency } \\
\text { Reduce attention to the criteria of creativity and innovation }\end{array}$ \\
\hline & $\begin{array}{l}\text { Decreased quality of banking prod- } \\
\text { ucts }\end{array}$ & $\begin{array}{l}\text { Unattractive deposit products } \\
\text { Unattractive credit products } \\
\text { Decreased quality of IT tools }\end{array}$ \\
\hline & Improper risk management & $\begin{array}{c}\text { Lack of attention to the concept of cost -benefit of custom- } \\
\text { ers } \\
\text { Lack of attention to credit, financial and liquidity risk }\end{array}$ \\
\hline & $\begin{array}{l}\text { Inadequate leadership skills of the } \\
\text { branch manager }\end{array}$ & $\begin{array}{c}\text { Non-charismatic personality without interaction } \\
\text { Introverted character } \\
\text { Low level of knowledge, personal studies and knowledge } \\
\text { management skills }\end{array}$ \\
\hline & $\begin{array}{l}\text { Improper combination of personality } \\
\text { and age of the branch team }\end{array}$ & $\begin{array}{l}\text { Significant share of the number of passive characters in the } \\
\text { team } \\
\text { Average job experience very low or very high }\end{array}$ \\
\hline $\begin{array}{l}\text { Background condi- } \\
\text { tions }\end{array}$ & $\begin{array}{c}\text { Improper pressures, behaviors and } \\
\text { procedures }\end{array}$ & $\begin{array}{c}\text { Public references } \\
\text { Regulatory authorities } \\
\text { The pressures of judicial institutions and other institutions } \\
\text { Customers' opportunistic behaviors and attitudes } \\
\text { Non-professional business rivals } \\
\text { Inappropriate conditions in the context of banking industry }\end{array}$ \\
\hline \multirow[t]{2}{*}{ Strategies } & Poor quality decision & $\begin{array}{c}\text { Failure to open in the basics of health and financial safety } \\
\text { Inadequate recognition of financial safety threats } \\
\text { Inadequate analysis of problems and disorders } \\
\text { Indecision or decisions late }\end{array}$ \\
\hline & Poor execution of decisions & $\begin{array}{l}\text { Improper or incompatible actions } \\
\text { Lack of reform policies } \\
\text { Lack of follow-up for complementary therapies } \\
\text { Failure to run a continuous check-up program }\end{array}$ \\
\hline \multirow[t]{2}{*}{ Interfering conditions } & Improper short-term procedures & $\begin{array}{l}\text { Non-interactive budgeting of BSC branch indicators } \\
\text { Credit policies and non-native claims of the bank } \\
\text { Improper marketing and advertising practices } \\
\text { Lack of sensitivity analysis calculations in the BSC bank sys- } \\
\text { tem } \\
\text { Structural ambiguities and intra-organizational processes } \\
\text { not updated } \\
\text { Instability in unit management }\end{array}$ \\
\hline & Long-term inappropriate procedures & $\begin{array}{c}\text { Improper training procedures } \\
\text { Insufficiency of control and internal supervision of the } \\
\text { branch } \\
\text { Employee involvement with repetitive routines } \\
\text { Decline in the level of emotional and financial intelligence } \\
\text { of the branch team } \\
\text { Opportunistic behaviors and attitudes of employees } \\
\text { History of the branch }\end{array}$ \\
\hline Consequences & $\begin{array}{l}\text { Early formation of financial syn- } \\
\text { drome }\end{array}$ & \\
\hline
\end{tabular}




\begin{tabular}{|c|c|c|}
\hline & $\begin{array}{c}\text { Formation of indifference disorder } \\
\text { syndrome }\end{array}$ & \\
\cline { 2 - 3 } & $\begin{array}{c}\text { Development of financial syndrome } \\
\text { and branch merger }\end{array}$ & \\
\hline
\end{tabular}

\section{Discussion}

The results of open and axial coding were the estimation of 53 primary codes in the form of 11 categories out of 280 concepts. In the present study, imbalances and declining health levels and declining financial safety formed the central dimension of the branch, which is directly related to the categories of declining adherence to organizational ethics values in the branch team, declining quality of banking products, improper risk management, inappropriate personality and leadership skills. The branch, the inappropriate combination of personality and age of the branch team were affected as causal conditions. This finding is consistent with research that emphasizes the role of organizational ethics values in healthy banking (16-14). It is also consistent with studies that emphasize the role of bank management in bank returns $(17,18)$.

According to the results of the present study, inappropriate pressures, behaviors and procedures cause the decline of balance, health and financial safety of the branch. This finding is in line with a study that examines the legal authority of the banking regulator and emphasizes the importance of the role of government, judicial and regulatory authorities in the banking industry (19).

Also, the results of the present study indicate poor quality decision making and poor-quality implementation of decisions as inappropriate actions, reactions and strategies to face the safety and health threats of the financial unit, which can be based on the results of research on the importance of decision making. The financial and banking systems need to be explained $(20,21)$.

Also in line with some studies in the present study, such as inappropriate marketing and advertising practices (22), instability in unit management (3), inappropriate training practices (23), lack or decline in emotional and financial intelligence of the branch team (24), the opportunistic behaviors and attitudes of employees (25) have been mentioned under the two categories of inappropriate shortterm and long-term procedures as intervening conditions.

Finally, in the present study, the categories of initial formation of financial syndrome, formation of indifference disorder to the syndrome and development of financial syndrome and branch merger have been mentioned as a consequence for bank imbalance and bank losses.

Based on the research findings, it is suggested to reduce the bank's loss level:

- The values of organizational ethics should be considered. In this regard, transparency of financial statements is one of the major ethical issues that plays an important role in the banking system. Depositors and shareholders have the right to access accurate and transparent information, and one of the goals of any banking system should be to create more transparency in the financial system.

- Considering the importance of the role of government, judicial and supervisory authorities in the banking industry and the formation of efficient regulatory systems, can undoubtedly prevent many moral corruptions in the banking system such as bribery, embezzlement, usury, unreality of some transactions, etc. It will take to create a bank loss syndrome.

- Choosing appropriate and efficient management that can make the right decisions at the right time is of great importance in the banking system because according to the results of this study, behind-the-scenes transactions and selection of inefficient managers, lack of transparency and inattention to auditing are reasons for banks.

- In general, in addition to the transparency of financial statements, evaluation of bank balance sheets, and proper monitoring of banks' 
performance, the prerequisites for reducing bank losses are changes in banking management, ensuring the accuracy of financial statements submitted by independent auditors. Successful banking practices in other countries, and eliminating distrust of the banking system through a targeted and long-term program, so that banks are sanitized and the capital adequacy ratio is improved.

\section{Conclusion}

The purpose of this study was to investigate the variables affecting the creation and development of bank loss syndrome with emphasis on ethical variables. Profitability is one of the influential factors in evaluating the performance of banks and will undoubtedly have banking imbalances, assets and liabilities gaps, cost-income gaps and cash flow imbalances with consequences such as the development of financial loss syndrome and branch mergers. Had. Based on the results of the present study, the causal conditions that cause banking imbalance and as a result of the bank loss syndrome, a decrease in adherence to the values of organizational ethics in the branch team (reducing attention to work and collective effort and providing enthusiastic and value-creating services, decreased attention to commitment, building trust and loyalty, accountability and transparency) decreased quality of banking products, inadequate risk management and inadequate leadership and leadership skills of the branch.

Therefore, along with the general conditions of the economy and inefficient management practices, ethics can be an important factor in the occurrence of bank loss syndrome. With the movement of economic sciences towards the exploitation of ethics, banking has also moved towards ethics, the main reasons for which are money laundering, embezzlement, usury, etc. Ethical banking and paying attention to ethical principles in the banking system is a way to deal with financial and non-financial crises and to create security, financial strength and authority and increase customer satisfaction. In other words, ethical banking, although not profit-oriented, indirectly reduces the banking loss syndrome. The results also showed that inappropriate pressures, behaviors and procedures in the areas of government, judiciary and supervision are the cause of bank loss syndrome and poor-quality decisions and poor execution of decisions can also be effective in this regard.

\section{Ethical Consideration}

Ethical issues such as; Plagiarism, informed consent; Duplications, etc. have been considered in the present study.

\section{Conflict of Interest}

The authors declare that there is no conflict of interests.

\section{Acknowledgement}

The authors would like to express their sincere thanks to the participants and the people who helped us in this research.

\section{References}

1. Ahmadian A, Heidari H (2013). Impact of macroeconomic conditions on banks and losses of banks. Monetary-Banking Research, 12: 71-99. (In Persian).

2. Hoseini-Dolatabadi SM(2015). The nature of the bank and its implications for Islamic banking studies. Journals of Islamic Economics Studies, 8(2): 173-198. (In Persian).

3. Zalbagi-Darestani $\mathrm{H}$ (2014). Factors affecting the stability of the banking network. Monetary-Banking Research, 7(20): 307-327. (In Persian).

4. Dadgar Y (2016). Feasibility study of interest-free banking modeling based on the theory of middle financial rationality. Journal of Islamic Economics \& Banking, 16: 203230. (In Persian).

5. Roghanian P, Rasli A, Gheysari H (2012). Productivity through effectiveness and efficiency in the banking industry. Social and Behavioral Sciences, 40: 550-556. DOI: https://doi.org/10.1016/i.sbspro.2012.03.229

6. Paradi JC, Rouatt S, Zhu H (2011). Two-stage evaluation of bank, branch efficiency using data envelopment analysis. Omega, 39(1): 99-109 .

7. Azizi A (2018). Financial crises and the reasons for the relative financial stability of Islamic banking at the international level. Legal Scientific Quarterly of Qamun Yar, 2(5): 1-16. (In Persian). 
8. Budlaee H, Kooshki-Jahromi A, Satarinasab R (2011). Organizational learning and trust, mediating links between psychological empowerment and organizational commitment. Management and Development Process, 75: 6893. (In Persian).

9. Akbarian R, Rafiee H (2007). Islamic banking: theoretical, practical challenges and solutions. Islamic Economy, 7(26): 97-118. (In Persian). DOI: https://dorl.net/dor/20.1001.1.20085907.1396.9.1.8.9

10. Dianati Z, Manteghi K, Ali-Esfahani Y (2018). The effect of bank type on corporate social responsibility reporting ethical approach. Ethics in Science \& Technology, 13(1). (In Persian).

11. Mousavi-Jahromi Y, Faezy SM (2010). The position of ethics in banking: A comparative study of ethical banking with Islamic banking. International Conference on Islamic Banking and Finance, Tarbiat Modares University/ Tehran.

12. Valerio C (2011). Banking on ethics. CRBM -Campagna per la Riforma Della Banca Mondiale, Italy.

13. Khosravineja R, Bahrami M, Barati M (2018). Analyzing the correlation between relationship marketing and brand equity of bank: the moderating role of business ethics. Ethics in Science and Technology, 13 (1):116-12. (In Persian). DOR: http://dorl.net/dor/20.1001.1.22517634.1397.13.1.14.6

14. Rahmani H (2016). Investigating the impact of professional ethics on organizational performance. Journal of $V$ alue and Bebavioral Accounting, 1(1): 53-76. (In Persian). DOI: $\quad$ http://dx.doi.org/10.18869/acadpub.aapc.1.1.53

15. Alizadeh R, GHolami H, Jahed MA. (2019). Business ethics as a paradigm of banking crime prevention. Ethics in Science and Tecbnology, 14(5). (In Persian). DOI: http://dorl.net/dor/20.1001.1.22517634.1398.14.5.6.3

16. Sadighi N, Mohammad-Davudi AH, Ghorbanhoseini M, Amini-Sabegh Z (2020). Identify and rank ethical components in the electronic banking industry. Ethics in
Science and Technology, 15(2). (In Persian). DOR: http://dorl.net/dor/20.1001.1.22517634.1399.15.2.6.4

17. Bahrami HR (2013). Investigating the factors affecting the continuation of losses of bank branches. Expert Report, 2: 95-96. (In Persian).

18. Alipour Shirsavar H, Gilaninia S, Mohammadi Almani A (2012). A Study of factors influencing positive word of mouth in the Iranian banking industry. Middle-East Journal of Scientific Research, 11(2): 454-460.

19. Elsun M (2012). Examining the legal authority of the banking regulatory body. Money and Economics, 9: 147177. (In Persian).

20. Fadaee-Nejad ME, Sadeghi SJ, Banaeian H (2011). Designing a decision support system for banking management from the perspective of equipping resources $(\mathrm{Ag}$ ricultural Bank case study). IT management, 6. (In Persian).

21. Khalili M (2005). Credit risk management by applying decision models. Economic Researh Joumal, 5(1): 183-212. (In Persian).

22. Asgharizadeh E, Amin F (2005). Increase the efficiency of banking services by prioritizing customers. Economic Policies \& Research, 13(36). (In Persian).

23. General Management of Supervision of Banks and Credit Institutions. (2004). Effective measures to manage and monitor operational risk. Available at: file:///C:/Users/Takta/AppData/Local/Temp/4 Oprational\%20risk.pdf

24. Taghizadeh M, Chirani E (2014). The relationship between managers' emotional intelligence and financial performance of bank branches in Guilan province. International Conference on Business Development and Excellence, Iran/Tehran.

25. Toulabi Z, Mohammadi E, Khodadaian B (2019). Provide a model for understanding the mistreatment costs of bank branch employees. Journal of Management Studies (Improvement and Transformation), 28(94): 9-38. (In Persian). 